\title{
Induction of biotransformation enzymes by polyhalogenated aromatic hydrocarbons (PHAHs): potential impact on animal physiology and health ${ }^{1}$
}

\author{
ABrah:IM BROUWER \\ Department of Tovicolog, Agricultural University, PO Box 8000, 6700 EA Wageningen, \\ The Netherlands.
}

Contact e-mail: hram.brouwer(a)algemeen.toc.wau.nl

\begin{abstract}
Biotransformation and its role in the elimination of polyhalogenated aromatic hydrocarbons (PHAHs) has been the subject of many studies from the late seventies onwards. The notion of specific, high affinity interactions of phenolic PHAH metabolites with the plasma transport proteins of thyroid hormone and vitamin $\mathrm{A}$, both in vitro and in viv, stimulated further research into the possible role of biotransformation in the toxicity of certain PHAHs such as PCBs. Currently, phenolic metabolites of PCBs and related compounds have been identified as major metabolites in blood plasma of e.g. grey seals (Halichoerus grypus) and humans with background environmental exposure to these chemicals. The concentrations of the hydroxy-PCBs were in the same range as the most persistent parent congeners, such as PCB 153,138 and 180 . These phenolic metabolites were found to possess a specific range of biological activities, which differed from the parent compounds. Another potential adverse effect associated with persistent induction of biotransformation enzymes, like UDP-glucuronyl transferases (UGTs) by PHAHs, is a long-term enhanced elimination of several important endogenous ligands such as vitamin $A$ and thyroid hormones. Reduced levels of vitamin $A$ and thyroid hormones have been reported in most experimental animal and wildlife species exposed to PHAHs. The recent observation of the accumulation of high levels of phenolic PCB metabolites in blood and brain of late gestational rat foetuses, in parallel with reductions in both vitamin $\mathrm{A}$ and thyroid hormone levels, suggests that these metabolites may play an important role in the observed developmental toxicity of PHAHs.
\end{abstract}

KEYWORDS: BIOMARKERS; DISEASE; HAZARD ASSESSMENT; PHYSIOLOGY; POLLUTION-HAHS; POLLUTION-ORGANOCHLORINES; REPRODUCTION

\section{INTRODUCTIOV}

Exposure of laboratory animals and wildlife species to various xenobiotic compounds usually causes an enhanced biotransformation response, in most cases resulting in an accelerated catalytic breakdown and elimination of the xenobiotics. Polycyclic aromatic hydrocarbons (PAHs) are an example of this class of xenobiotics. However, due to the highly reactive nature of some of the metabolic $\mathrm{PAH}$ intermediates formed, a certain fraction of the PAH metabolites will not be eliminated but rather will give rise to DNA and protein adducts and associated toxicity. On the other hand, there are several classes of very persistent polyhalogenated aromatic hydrocarbon (PHAH) pollutants, such as polychlorinated biphenyls (PCBs), dibenzo-p-dioxins (PCDDs) and dibenzofurans (PCDFs) (Fig. 1), that give rise to a high induction of biotransformation cnzymes, but are themselves hardly 
degraded and eliminated by the enzymes they induce. Consequences of a persistent induction of certain biotransformation enzymes, such as cytochrome P450 isozymes, may involve: increased oxidative stress; increased formation of reactive intermediates from more readily degradable xenobiotic compounds present in the same exposure matrix; and enhanced elimination of physiologically important endogenous ligands (hormones, vitamins). Therefore, these classes of persistent PHAH pollutants may put the exposed laboratory and wildlife species at risk from adverse health effects. In this paper several aspects of the metabolism and physiological/toxicological consequences of exposure to PCBs and related compounds are discussed.

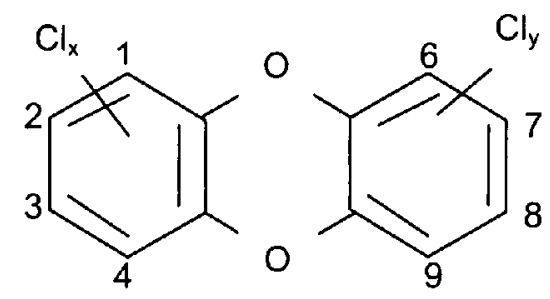

PCDD
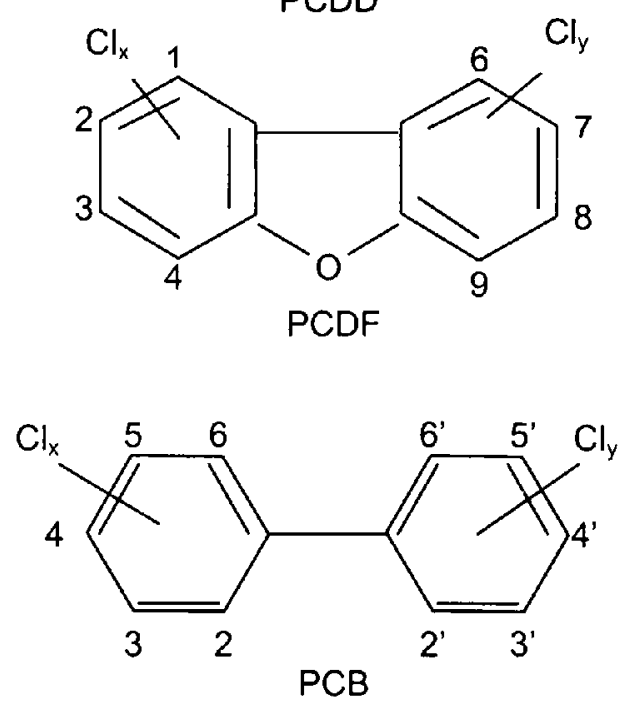

Fig. 1. General structures of PCDD, PCDF and PCB.

\section{POLYCHLORINATED BIPHENYLS, DIBENZO-P-DIOXINS AND RELATED COMPOUNDS}

PCBs are a class of ubiquitous and persistent environmental pollutants that accumulate extensively in food chains. All biota and species analysed so far have been found to contain a certain level of PCBs and related contaminants. Relatively high body burdens of PCBs and related compounds are found in species at higher trophic levels, especially those of the aquatic and marine environment. PCBs and related compounds are even detectable in marine species found in the Arctic and Antarctic, far from their source (e.g. harp seals, Phoca groentandica. Antarctic fur seals, Arctocephalus gacella, ringed seals, Phoca hispida and 
white whales, Delphinapterus leucas) due to the global transport of these persistent lipophilic compounds from warmer areas to colder areas (Norstrom and Muir, 1994; Oehme et al., 1994a). Body burdens of PCBs and related compounds have been found to be dependent on a variety of factors including species, age, gender, season, diet and location. Therefore, it is difficult to discern temporal trends. However, overall there was a decline in PCB levels in most species in the early eighties, which now seems to have levelled off, at least in some areas (Norstrom et al., 1988; Bignert et al., 1993; De Boer and Hagel, 1994).

\section{PHAH congener patterns}

PHAH congener patterns present in biota of various trophic levels differ considerably. These differences are mainly due to variations in exposure and/or biotransformation capacity of the various species. In general, only 2,3,7,8-substituted polychlorinated dibenzo-p-dioxins (PCDDs) and dibenzofurans (PCDFs) congeners are found in most biota, indicating a rapid degradation of the non-2,3,7,8-substituted PCDD/Fs by most species (Van den Berg et al., $1994 \mathrm{~b}$ ). The relative concentrations of the various $2,3,7,8-\mathrm{PCDD} / \mathrm{Fs}$ increase with the number of chlorine substituents. Therefore, the highest concentrations are observed for octaCDD/F congeners. However, for PCB congeners the picture is more complex. In fact, $\mathrm{PCB}$ congeners have been divided into six structurally different groups of congeners that differ in their biostability. Some congeners appear to be very persistent, like the CB congeners 153,138 and 180 . However, the CB congener pattern differs between different species dependent on, for instance their biotransformation capacity. This is well illustrated by the variation of the ratio of the different non-ortho substituted, co-planar CBs, 3,3'.4.4'-TeCB (CB 77), 3,3',4,4',5-PeCB (CB 126) and 3,3',4,4',5,5'-HxCB (CB 169) in various species (Kannan et al., 1988; 1989a; b). In fish, crabs and blue mussels, CB 77 represents $>90 \%$ of the non-ortho CBs in areas around Japan (Miyata et al., 1994) and Taiwan (Lu et al., 1994) and actually reflects the ratio of non-ortho CBs present in river sediments (Ohsaki et al., 1994). In marine mammals, like Antarctic fur seals and harp seals, CB 77 and CB 126 are present in blubber in almost equal amounts, while CB 169 is present at a ratio of 0.1-0.2 towards CB 126 (Oehme et al., 1994a; b). However, in human milk samples CB 77 is only a small proportion $(<10 \%)$ of the non-ortho $\mathrm{CB}$ congeners (Koopman-Esseboom et al., 1994).

\section{PHAHs and toxicity}

PCBs have been found to cause a wide spectrum of species-specific and congener-specific toxic and biochemical effects in experimental animals, including hepato-, immuno-, reproductive-, and dermal-toxicity, teratogenicity (congenital malformations), developmental neurotoxicity and carcinogenicity (McConnell, 1989; Safe, 1994). In general, early exposure during embryonal and neonatal development is a much more sensitive (more than 100-fold) time period than adult exposure for induction of adverse effects in laboratory animals and probably also in human infants (Brouwer et al., 1995). Moreover, the effects induced early on in life have a much greater chance of being permanent without possibilities for compensation. In addition, PCBs and related compounds have been suggested to be involved in many epizootic diseases in fish, birds and marine mammals, such as 'blue sac like disease' in fish (Peterson et al., 1993), skin lesions and liver tumors in flounder, Platichthys flesus, (Vethaak, 1993); reduced immune function in relation to outbreaks of lethal morbillivirus infections in seals in the North Sea and Baltic (Brouwer et al., 1989b; De Swart et al., 1994; Ross et al., 1995, although see Kennedy, 1999); and reduced population size due to reproduction problems in ringed, pusa hispida, harbour seals, Phoca vitulina, (Helle et al., 1976; Reijnders, 1986) and fish-eating birds, such as cormorants, 
Phalacrolorax carbo, (Van den Berg et al., 1994a). Early life stages in wildlife species also appear to be much more sensitive than adults for the adverse health effects of PCBs and related compounds (Colborn and Clement, 1992).

\section{PHAHs and Ah-receptor}

Most of the toxic and biochemical effects induced by planar, non-ortho substituted PCBs and 2,3,7,8-substituted PCDD and PCDF congeners are mediated through high affinity binding to a cytosolic protein, the aryl hydrocarbon-receptor (AhR; Poland and Knutson, 1982). After ligand binding the AhR is converted into an activated, DNA-binding form, subsequently transformed by the release of two heat shock proteins (HSP90) and translocated to the nucleus and complex formation to a second protein, the Ah-receptor nuclear translocator (ARNT; Whitlock, 1993; Hankinson, 1995). This heterodimer complex is bound to specific sequences, the dioxin responsive enhancer (DRE) sequences located in the promotor-region upstream of dioxin-responsive genes (Denison et al., 1988a; b).

Nowadays a number of genes have been identified that contain one, or several DREs, and therefore their expression may be regulated via the dioxin-AhR pathway. A number of the DRE-containing genes encode cytochrome P450 isozymes, such as CYP1A1, CYP1A2, CYP1B1. In addition, several conjugation enzymes are identified with DREs in their promotor region, such as aldehyde dehydrogenase (Ahd4) gene, $\mathrm{NAD}(\mathrm{P}) \mathrm{H}$-menadione oxidoreductase $(\mathrm{Nmol})$ gene, UDP-glucuronyl transferase (UGT01*6) gene and the Glutathion-S-transferase (GST-pi) gene (Nebert et al., 1993).

\section{Induction of biotransformation enzymes}

In laboratory rodents (mice, rats, guinea pigs) planar, non-ortho substituted PCBs cause a 50 -fold to several hundred fold persistent induction of CYP1A1/2 activity, similar to 3-methylcholanthrene (3-MC), which therefore is also called 3-MC type of induction. However, in contrast to 3-MC, the CYP1A1/2 induction caused by the planar PCBs is persistent, reflecting the long half-life of PCB congeners in most species. A frequently used model substrate for CYP1AI/2 is ethoxyresorufin, which is deethylated during the enzymatic reaction. This activity is called ethoxyresorufin-O-deethylase (EROD). Another frequently used model substrate is benzo(a)pyrene, and in this case the corresponding enzymatic activity is called arylhydrocarbon hydroxylase (AHH). These activities are extensively used as markers for CYP1 A1/2 induction by PHAHs (Safe, 1994). Several of the other AhR-pathway controlled gene products have also been found to be induced, such as increased UGTl with associated increases in hepatic thyroxine $\left(T_{4}\right)$ and 1-naphtol glucuronidation, following exposure of laboratory animals to PCBs and related compounds (Visser et al., 1993; Van Birgelen et al., 1995).

However, non-planar PCB congeners, such as diortho-substituted PCBs, do not cause induction of CYP1Al/2 genes, but instead induce CYP2B1/2 isozymes, similarly to phenobarbitone (PB). Because of this, such activity is also called PB-type of induction. A model reaction for $\mathrm{CYP} 2 \mathrm{~B}$ is the depentylation of pentoxyresorufin (PROD). The mechanism of CYP2B gene induction is less clear than that of CYP1Al/2. Both a receptor-mediated enhanced transcription and a post-transcriptional stabilisation of mRNAs have been suggested. In addition to CYP2B isozymes, PB-type inducers also enhance transcription of members of the CYP2C and CYP3A classes. Mono-ortho and some di-ortho substituted PCB congeners are so-called mixed type inducers' in that, they induce both CYP1A and CYP2B classes of isozymes.

In general, induction of orthologous CYP450 isozymes by PHAHs is also observed in wildlife species, like fish, fish-eating birds and marine mammals. In fish, CYPlAl and the associated EROD activity is induced by PHAHs via an AhR mediated pathway (Hahn and 
Stegeman, 1994). In the case of fish caught in the wild with different levels of environmental exposure to PHAHs, the correlation between exposure and EROD-induction is often less clear. This may be due partly to the problems associated with exposure of species in the wild to complex mixtures of PCBs and related compounds. Several PCB congeners, such as CB 77, appear to be able to competitively inhibit the EROD activity (Hahn and Stegeman, 1994; Morse et al., 1995). In addition, several publications indicate the presence of Ah-receptor antagonists in PCB mixtures that partly abolish the EROD induction by 2,3,7,8-TCDD (Davis and Safe, 1990; Aarts et al., 1993). Fish-eating birds, like the common tern (Sterna hirundo) and cormorants, as well as marine mammals, like harp seals and harbour porpoises (Phocoena phocoena) also show a good CYPIA1/2 inducibility following exposure to PHAHs (Goksoyr et al., 1992; Van den Berg et al., 1994a; Bosveld et al., 1995). A major distinction between laboratory animals and fish and most fish-eating birds, is the absence of CYP2B isozymes in the latter species. However, there is limited information on the presence and inducibility of CYP2B isozymes in marine mammals (Goksøyr et al., 1992; White et al., 1994: Kannan et al.. 1995).

\section{CONGENER PATTERNS IN DIFFERENT SPECIES}

Comparison of congener patterns between sediments and fish, fish and marine mammals, fish and fish-eating birds, may provide valuable information on the metabolism of certain $\mathrm{PHAH}$ congeners. By comparing ratios of a non-metabolisable PHAH congener, like CB 153 with the other $\mathrm{CB}$ congeners in different matrices one can deduce the relative impact of metabolism on PHAH congener patterns (Boon et al., 1992). Only 2,3,7,8-substituted $\mathrm{PCDD} / \mathrm{Fs}$ are found in biota and species at higher trophic levels, such as marine mammals and man, indicating that the non-2,3,7,8-PCDD/Fs are rapidly metabolised in the environment (Van den Berg et al., 1994a). However, 2,3,7,8-TCDF which is present in biota is still rapidly metabolised in laboratory rats with a half-life of about two days. This 2,3.7,8-PCDF congener is probably quite extensively metabolised in marine mammals and human individuals as well. Metabolism of PCBs is more complex. PCB congeners have been divided into different structural groups with regards to cytochrome P450-dependent metabolism, based on experimental and field studies on seals and cetaceans (Boon et al., 1994). Congeners that contribute to dioxin-type toxicity in laboratory animals are given in bold in this list.

I: Congeners without any vicinal hydrogen (H) atoms (e.g. CB153, CB169, CB180, CB183, CB 187, CB 194).

II: Congeners with vicinal $\mathrm{H}$ atoms only in the ortho- and meta-positions in combination with $\geq 2$ ortho-Cl substituents (e.g. CB99, CB128, CB138, CB170).

III: Congeners with vicinal $\mathrm{H}$ atoms in the ortho- and meta-positions in combination with $\leq 1$ ortho - CL (e.g., CB-28, CB77, CB105, CB118, CB126, CB156).

IV: Congeners with vicinal $\mathrm{H}$ atoms in the meta- and para-positions in combination with $\leq 2$ ortho-Cl (e.g. CB44, CB49, CB52, CB 101, CB 110 ).

$\mathrm{V}$ : Congeners with vicinal $H$ atoms in the meta- and para-positions in combination with $\geq 3$ ortho-CL (e.g. CB136, CB149, CB151)

VI: Congeners with vicinal $\mathrm{H}$ atoms both in the ortho- and meta-positions and meta- and para-positions in combination with $\leq 1$ ortho- $\mathrm{Cl}$ (e.g. CB31) 
In seals, cetaceans and seabirds, congeners belonging to Groups $\mathbf{l}$ and II are persistent to biotransformation but, in polar bears, even some of these congeners appear to be metabolisable, especially when at least one unsubstituted para-position is available (Norstrom et al., 1988). Congeners of Group III are metabolisable (by CYP1A) in seals, harbour porpoises and dolphins. This is important because Group III contains most of the dioxin-type congeners. The capacity to metabolise congeners belonging to Groups IV and V seems to be more developed in seals than in cetaceans (Tanabe et al., 1988), although there is evidence for biotransformation of congeners of Group IV (Duinker et al., 1989; Boon et al., 1994) and even Group V congeners (Reijnders, 1994; Bruhn et al., 1995; Reijnders and de Ruiter-Dijkman, 1995) by the harbour porpoise too. The substitution pattern at the four available ortho-positions has two possible consequences: it strongly influences the ability of the molecule to reach a planar configuration (Cullen and Kaiser, 1984) which is very important for expressing dioxin-like toxicity, or the bulky chlorine atoms may simply prevent enzymatic attack.

\section{Role of CYP1A1/2 in PHAH metabolism}

In vitro incubations of a radiolabelled model compound ( $\left.{ }^{4} \mathrm{C}-\mathrm{CB} 77\right)$ in hepatic microsomal preparations from rats pretreated with different inducers of $\mathrm{P} 450$ isozymes, clearly indicated the importance of CYP1A1/2 in the phenolic CB metabolite formation (Ishida et al., 1991: Morse et al., 1995). The mechanism of CYPIA1/2-dependent formation of phenolic CB metabolites is thought to involve the formation of highly reactive arene oxide intermediates, which may spontaneously rearrange to phenols with a concomittant shift of substituents from the site of hydroxylation to the next neighbour carbon atom in the aromatic ring. Phenolic $\mathrm{CB}$ metabolites have been identified as major metabolites of both planar and non-planar CBs in in vitro and in vivo studies (Klasson-Wehler, 1989; Safe, 1989).

The rate of formation and the nature of the phenolic $\mathrm{CB}$ metabolites formed are both species and congener dependent (Murk et al., 1994b). In general, hydroxylation is favoured in the para-position of the least chlorinated ring. However, a phenolic derivative of $2,3,3^{\prime}, 4^{\prime}, 5$-PeCB with the hydroxy-group in the most chlorinated ring was recently identified as the major metabolite present in blood plasma of mice (Bergman et al., 1994). Phenolic products are the major PCB metabolites formed in in vitro incubations with liver microsomes and in vivo by mammalian and avian species (Murk et al.. 1994b). However, in liver microsomes of fish minimal formation of phenolic-PCB metabolites was observed, even when exposed experimentally to cytochrome P450-1 Al/2 inducers.

\section{TOXICOLOGICAL CONSEQUENCES OF PERSISTENT CYP1A1/2 INDUCTION BY PHAHs}

\section{(a) Phenolic PCB related effects}

Metabolism and metabolite formation of most halogenated aromatic compounds, including PCBs have been regarded mainly as an climination and detoxification route. Recent studies have indicated that phenolic and methylsulphone metabolites of PCBs and related compounds are not readily excreted, but instead may be present in relatively large quantities in organs and body fluids for a prolonged time period. For example, relatively large amounts of phenolic PCB metabolites have been identified in blood plasma of several species (e.g. rats, mice, marine mammals and humans) either experimentally or environmentally exposed to PCBs (Klasson-Wehler et al., 1992: Bergman et al.. 1994). Moreover, a considerable accumulation of phenolic PCB metabolites was observed in late gestational foetuses when their mothers were exposed to Aroclor 1254 from days 10 to 16 of gestation (Morse, 1995; Morse et al., 1995). 


\section{Effects on thyroid hormone metabolism and transport}

Several studies have indicated that phenolic metabolites of PCBs and related compounds do have their own metabolite-specific range of biological activities and may also add to some parent compound-specific biological effects (Table 1). Phenolic PCB metabolites are much more potent than their respective parent compounds in terms of interference with thyroid hormones for their key proteins in transport and metabolism. For example, phenolic PCBs competitively inhibit thyroxine $\left(T_{4}\right)$ binding to transthyretin (TTR; Lans et al., 1993). TTR is the major plasma transport protein of $\mathrm{T}_{4}$ in most species, except in larger mammals including humans. Phenolic metabolites of PCBs are also much more potent than their parent compounds with respect to competitive inhibition of hepatic type 1-deiodinase (Adams et al., 1990), a pivotal enzyme in the activation/deactivation of thyroid hormone. Moreover, phenolic metabolites, but not their corresponding parent compounds are potent uncouplers of oxidative phosphorylation in rat liver mitochondria (Lans et al., 1990; Narasimhan et al., 1991). Next to these in vitro observations there are also in vivo observations indicating that both TTR and type 1-deiodinase activities are affected by phenolic metabolites of PCBs (Brouwer and Van den Berg, 1986; Adams et al., 1990).

Table 1

Observed in vitro biological effects of phenolic PCB mctabolites and relative potency towards parent compounds. TTR: transthyretin; IC: intercellular communication; > or <: order of magnitude.

\begin{tabular}{ll}
\hline Biological effects of phenolic PCBs & Potency relative to parent compound \\
\hline$T_{\perp}$ - binding competition on TTR & OH-PCBs $\gg$ PCBs \\
Inhibition of type 1- deiodinase & OH-PCBs $\gg$ PCBs \\
Uncoupling mitochondrial respiration & OH-PCBs $\gg$ PCBs \\
Oestrogen receptor binding & OH-PCBs $>$ PCBs \\
Ah-receptor binding (rat liver cytosol) & OH-PCBs $<$ PCBs \\
IC inhibition (Hepalclc7) & OH-PCBs $<$ PCBs \\
Chick embryo mortality & OH-PCBs $\ll$ PCBs \\
EROD induction (Hepalc 1c7) & OH-PCBs $\ll$ PCBs \\
\hline
\end{tabular}

\section{Effects on the oestrogen system}

Another interesting finding is that phenolic PCB metabolites, especially lower chlorinated ones, such as 4-hydroxy-2, $4^{\prime}, 6^{\prime}$-trichlorobiphenyl, show a substantial oestrogen receptor binding affinity, with a relative potency of 0.05 towards oestradiol (Korach et al., 1987). Interestingly, Aroclor 1221 has been shown to increase uterine weight (an oestrogenic activity) in vivo in female rats (Gellert, 1978). Increases in uterine weight have also been observed in immature rats, following exposure to 2,2',5,5'-tetrachlorobiphenyl, the Aroclor 1242 mixture and the phenolic metabolite 4'-OH-2,4,6-trichlorobiphenyl (Jansen et al., 1993). It has been suggested that phenolic PCB metabolites may be more potent with respect to oestrogenic activity than their respective parent compounds, but the experimental evidence is scarce.

\section{Effects on the Ah-receptor pathway}

Ah-receptor binding has also been observed for some phenolic metabolites of $\mathrm{CB} 77$ (Klasson-Wehler et al., 1990). The Ah-receptor binding affinities of 2-OH, 4-OH and 5-OH metabolites of CB77 were quite remarkable, only about two to three times lower than those for the parent compound CB77 itself, using rat liver cytosols. However, the potency to induce the Ah-receptor mediated EROD activity was three orders of magnitude lower for the 
phenolic metabolites than for the parent CB77 compound itself, when using mouse Hepalclc7 cells (De Haan et al., 1994). This striking difference may indicate that substantial metabolism of phenolic PCBs to more polar derivatives may take place in Hepalclc7 cells.

\section{Effects on intercellular communication}

Intercellular communication (IC) is an important regulatory mechanism for cell proliferation and differentiation. Recently, we have obtained evidence that phenolic metabolites of CB77 are also able to inhibit gap junctional IC in mouse Hepalclc7 cells (De Haan et al., 1994). IC inhibition is believed to be an in vitro indicator of the tumor promotion potential of chemicals. The potency to inhibit IC for the phenolic CB77 metabolites was equal or higher than for the parent $\mathrm{CB} 77$. At the present time it is unclear as to whether the intrinsic potency of phenolic PCBs to inhibit IC may be even higher, due to the possibility of substantial secondary metabolism of these metabolites in mouse Hepalclc7 cells.

\section{In vivo toxicity of phenolic metabolites}

The in vivo toxic potency of phenolic metabolites relative to the parent compound $\mathrm{CB} 77$ is at least two orders of magnitude lower when tested in the chick embryo assay (Klasson-Wehler et al., 1990). In addition, acute exposure of rats to phenolic metabolites of PCBs resulted in much less toxicity compared to their corresponding parent compounds (Yoshimura et al., 1987; Koga et al., 1990). However, it may not be possible to delineate the intrinsic toxic potency of phenolic PCBs from these in vivo studies. A large proportion of the phenolic PCBs, which were given as a bolus ip injection, may never have reached their target sites, due to secondary metabolism. Phenolic metabolites formed in vivo are extensively packaged into specific binding proteins, such as TTR. This may affect both the rate of secondary metabolism and the ligand concentration at the target sites, due to a TTR-specific delivery route, such as to the foetal compartment (Morse, 1995). Therefore, exposure studies with phenolic PCBs bound to their specific binding proteins, such as TTR, will be performed in our laboratory to investigate their toxic potency.

\section{(b) Cypla1/2-induction and co-carcinogenesis}

Induction of CYP1 A 1/2 and other isozymes also increases the metabolic capacity of the liver towards other xenobiotic compounds that may be present in the same exposure matrix, such as the polycyclic aromatic hydrocarbons (PAHs). Numerous studies have shown the cytochrome $\mathrm{P} 450$-dependent accelerated rate of formation of mutagenic, reactive intermediates of PAHs (Dipple et al., 1984; Yang et al., 1984). The well investigated bay-region diol-epoxides, such as benzo(a)pyrenc-7,8-diol,9,10-epoxide, are highly mutagenic and readily form DNA-adducts. The formation of carcinogenic metabolites from PAHs by $\mathrm{P} 450$ isozymes is highly regio- and stereoselective. For eximple, the isozyme CYPIA2 is highly selective in the formation of 3,4-dihydrodiol metabolites from 7-methylbenz(c)acridine, while CYP3A4 is mainly involved in the proximate carcinogenic metabolite formation from dibenz(a,j)acridine (Roberts-Thomson et al., 1995). There appears to be a good relationship between cytochrome P450 isozyme induction potency and the mutagenicity of the PAH-metabolites formed. Therefore, it is anticipated that a persistent exposure to $\mathrm{PCBs}$ and related $\mathrm{P} 450$ isozyme inducers may enhance the risk for co-carcinogenic events considerably when individuals are exposed to complex mixtures of PHAHs and PAHs present in the environment. 


\section{(c) Enhanced metabolism of endogenous substrates}

Another observed consequence of long-term induction of biotransformation enzymes by PCB exposure is an accelerated metabolism and elimination of endogenously important components, such as vitamins and hormones. In this case, the enhanced elimination of endogenous compounds may not be due to CYPIA1/2, but to concommitantly induced enzymes such as UDP-glucuronyl transferases. Many studies have found an enhanced hepatic glucuronidation of thyroxine $\left(T_{4}\right)$ and a concommittantly reduced level of $T_{4}$ in plasma of experimental animals exposed to PCBs and related compounds (Bastomsky, 1977; Collins and Capen, 1980; Visser et al., 1993; Van Birgelen et al., 1995). Both 3-MC and PB-type inducers can cause an accelerated hepatic glucuronidation of $\mathrm{T}_{4}$, though through different isozymes, UGT1 and UGT2 (Visser et al., 1993). Complex PCB mixtures may therefore possess a high potential to induce $\mathrm{T}_{4}$-glucuronidation, since both planar and non-planar PCBs may contribute to this effect. Enhanced glucuronidation of certain vitamin A (retinoid) derivatives, such as retinoic acid, was also observed following incubation with hepatic microsomes of TCDD-pretreated rats (Bank et al., 1989; Zile et al., 1989). This enhanced conjugation of retinoid derivatives may also be involved in the dramatic depletion of hepatic and extrahepatic retinoid concentrations in laboratory animals exposed to PHAHs (Brouwer et al., 1988; 1989a; Håkansson et al., 1991; Chen et al., 1992).

Reductions in both vitamin A and thyroid hormone levels in relation to PHAH exposure have been observed in several fish-eating bird species and in marine mammals (Brouwer et al., 1989b; De Swart et al., 1994; Murk et al., 1994a; c; Van den Berg et al., 1994a). In addition, Murk et al. (1994a; c) recently found a significant correlation between $\mathrm{T}_{4}$-glucuronidation and PCB body burdens in common terns.

\section{CONCLUSION}

In conclusion, persistent induction of P450 isozymes by environmental pollutants, such as CYP1A1/2 by PHAHs, may put individuals (laboratory animals, wildlife species and man) at risk from adverse health effects, such as developmental toxicity and carcinogenesis. Therefore, given the long-lasting and relatively high levels of exposure of marine mammals to a variety of persistent chemical pollutants, it is of utmost importance to develop and use mechanistically-based biomarkers for PHAHs and other pollutants to monitor exposure levels and subtle indications of effects.

\section{ACKNOWLEDGEMENTS}

The author is grateful to D.C. Morse, Department of Toxicology, Agricultural University Wageningen and J.P. Boon, Netherlands Institute for Sea Research (NIOZ), Texel, The Netherlands for their critical reading of the manuscript and valuable suggestions.

\section{REFERENCES}

Aarts, J.M.M.J.G., Denison, M.S., De Haan, L.H.J., Cox, M.A., Schalk, J.A.C. and Brouwer, A. 1993. Antagonistic effects of diortho PCBs (PCB 52 and 128) on Ah-receptor-mediated induction of luciferase activity by 3,3',4,4-tetrachlorobiphenyl (PCB 77) in mouse Hepa-1clc7 cells. Organohalogen Compounds 14:69-72.

Adams, C., I ans, M.C., Klasson-Wehler, E., Van Engelen, J.G.M., Visser, T.J. and Brouwer, A. 1990. Hepatic thyroid hormone 5'-deiodinase, another target protein for monohydroxy metabolites of 3,3',4,4'-tetrachlorobiphenyl. Organohalogen Compounds 1:51-4.

Bank, P.A., Salyers, K.L. and Zile, M.H. 1989. Effect of tetrachlorodibenzo-p-dioxin (TCDD) on the glucuronidation of retinoic acid in the rat. Biochem. Biophys. Acta 993:1-6. 
Bastomsky, C.H. 1977. Enhanced thyroxine metabolism and high uptake goiters after a single dose of 2.3,7,8-tetrachlorodibenzo-p-dioxin. Endocrinology 101:292-6.

Bergman, $\AA$., Klasson-Wehler, E. and Kuroki, H. 1994. Selective retention of hydroxilated PCB metabolites in blood. Environ. Health Perspect. 102:464-9.

Bignert, A., Göthberg. A., Jensen. S., Litzén. K., Odsjö, T., Olsson, M. and Reutergårdh, L. 1993. The need for adequate biological sampling in ecotoxicological investigations: a retrospective study of twenty years pollution monitoring. Sci. Total Environ. 128:121-39.

Boon, J.P., Van Arnhem, E., Jansen, S., Kannan, N., Petrick, G., Schultz, D., Duinker, J.C., Reijnders, P.J.H. and Goksøyr, A. 1992. The toxicokinetics of PCBs in marine mammals with special reference to possible interactions of individual congeners with the cytochrome P450-dependent monooxygenase system: an overview. pp. 119-59. In: C.H. Walker and D.R. Livingstone (eds.) Persistant Pollutants in Marine Ecosyst'm.s. SETAC Special Publications Series. 1st. Edn. Pergamon Press, Oxford.

Boon, J.P., Oostingh, I., Van der Meer, J. and Hillebrand, M.T.J. 1994. A model for the bioaccumulation of chlorobiphenyl congeners in marine mammals. Eur. J. Pharmacol.: Env. Toxicol. Pharmacol. Section 270:237-51.

Bosveld, A.T.C., Gradener, J., Murk, A.J., Brouwer, A., Van Kampen, M., Evers, E.H.G. and Van den Berg, M. 1995. Effects of PCBs, PCDDs and PCDFs in common tern (Sterna hirundo) breeding in estuarine and coastal colonies in the Netherlands and Belgium. Emiron. Toxicol. Chem. 14:99-115.

Brouwer, A. and Van den Berg, K.J. 1986. Binding of a metabolite of 3,4,3,4'-tetrachlorobiphenyl to transthyretin reduces serum vitamin $A$ transport by inhibiting the formation of the protein complex, carrying both retinol and thyroxin. Toxicol. Appl. Pharmacol. 85:301-12.

Brouwer, A., Kukler, A. and Van den Berg, K.J. 1988. Alterations in retinoid concentrations in several extrahepatic organs of rats by 3,4,3',4'-tetrachlorobiphenyl. Toxicology 50:317-30.

Brouwer, A., Håkansson, H., Kukler, A., Van den Berg, K.J. and Ahlborg, U.G. 1989a. Marked alterations in retinoid homeostasis of Sprague-Dawley rats induced by a single ip dose of $10 \mu \mathrm{g} / \mathrm{kg}$ of 2,3,7,8-tetrachlorodibenzo-p-dioxin. Toxicology 58:267-83.

Brouwer, A., Reijnders, P.J.H. and Koeman, J.H. 1989b. Polychlorinated biphenyl (PCB)-contaminated fish induces vitamin A and thyroid hormone deficiency in the common seal (Phoca vitulina). Aquat. Toxicol. 15:99-106.

Brouwer, A., Ahlborg. U.G., Van den Berg, M., Birnbaum, L.S., Boersma, E.R., Bosveld. A.T.C., Denison. M.S., Hagmar, L., Holene, E., Huisman, M., Jacobson, S.W., Jacobson, J.I., Koopman-Esseboom, C., Koppe, J.G., Kulig, B.M., Morse, D.C., Muckle, G., Peterson, R.E., Sauer, P.J.J., Seegal, R., Smits-van Prooije, A.E., Touwen, B.C.L., Weisglas-Kuperus, N. and Winneke, G. 1995. Functional aspects of developmental toxicity of polyhalogenated aromatic hydrocarbons in experimental animals and human infants. Eur. J. Pharmacol. 293:1-40

Bruhn, R., Kannan, N., Petrick, G., Schulz-Bull, D.E. and Duinker, J.C. 1995. CB pattern in the harbour porpoises: bioaccumulation, metabolism and evidence for cytochrome P450 IIB activity. Chemosphere $31: 3721-32$

Chen, L.-C., Berberian, I., Koch, B., Mercier, M., Azais-Braesco, V., Glauert, H.P., Chow. C.K. and Robertson. L.W. 1992. Polychlorinated and polybrominated biphenyl congeners and retinoid levels in rat tissues: structure-activity relationships. Toxicol. Appl. Pharmacol. 114:47-55

Colborn, T. and Clement, C. 1992. Consensus statement: statement from the work session on chemically induced alterations in sexual development: the wildlife/human connection. p. $8 . \mathrm{m}$ : T. Colborn and C. Clement (eds.) Chemically induced alterations in sexual and functional deviopment: the wildlife ionnetion. Princeton Scientific Publishing. Princeton. New Jersey.

Collins. W.T. and Capen, C.C. 1980. Biliary excretion of $125 \mathrm{I}$-thyroxine and fine structural alterations in the thyroid glands of Gunn rats fed polychlorinated biphenyls (PCB). Lah. Invest. 43:158-64.

Cullen, J.M. and Kaiser, K.L.E. 1984. An examination of the role of rotational batriers in the toxicology of PCBs. In: K.L..E. Kaiser (ed.) QSAR in Environmental Tovicolegy. Reidel Publishing Company.

Davis, D. and Safe, S.H. 1990. Immunosuppressive activities of polychlorinated biphenyls in C57BL/6N mice: structure-activity relationships as $\mathrm{Ah}$ receptor igonisis and partial intagonists. Toxicology 63:97-111.

De Borer, J. and Hagel, P. 1994. Spatial differences and temporil trends of chlorobiphenyls in yellow eels (Anguilla allguilla) from inland water of The Netherlands. Sci. Total Emiron. 141:155-74.

De Haan, L.I1.J., Van Dijk, L. and Brouwer, A. 194. I. Elects of hydroxylated PCB metabolites on the Gap Junctional Intercelluar Communication between mouse llepalcle7 cells. Organohalogen Compounds 20:491-5.

Denison, M.S., Fisher, J.M. and Whitlock, J.P. 1988a. The DNA recognition site for the dioxin-Ah receptor complex: nucleotide sequence and functional analysis. J. Biol. Chem. 263:17221-4.

Dinison. M.S.. Fisher, J.M. and Whitlock. J.P. 1988b. Inducible, receptor-dependent protein-DNA interactions at a dioxin-responsive transcriptional enhancer. Proc. Natl tictel. Sci. U/SA 85:2528-32. 
De Swart, R.L., Ross, P.S., Vedder, L.J., Timmerman, H.H., Heisterkamp, S.H., Van Loveren, H., Vos, J.G., Reijnders, P.J.H. and Osterhaus, A.D.M.E. 1994. Impairment of immune function in harbour seals ( $P$ hoca vitulina) feeding on fish from polluted waters. Ambio 23:155-9.

Dipple, A.. Moschel, R.C. and Bigger, C.A.H. 1984. Polynuclear aromatic hydrocarbons. pp. 41-163. In: C.E. Searle (ed.) Vol. 1. Chemical Carcinogens. 2nd. Edn. American Chemical Society, Washington.

Duinker, J.C., Zeinstra. T., Hillebrand, M.T.J. and Boon, J.P. 1989. Individual chlorinated biphenyls and pesticides in tissues of some cetacean species from the North Sea and the Atlantic Ocean: tissue distribution and biotransformation. Aquat. Mamm. 15(3):95-124.

Gellert, R.J. 1978. Uterotropic activity of polychlorinated biphenyls (PCB) and induction of precocious reproductive ageing in neonatally treated female rats. Environm. Res. 16:123-30.

Goksøyr, A., Beyer, J., Larsen, H.E., Andersson, T. and Förlin, L. 1992. Cytochrome P450 in seals: monooxygenase activities, immunochemical cross-reactions and response to phenobarbital treatment. Mar. Environ. Res. 34:113-6.

Hahn, M.E. and Stegeman, J.J. 1994. Regulation of cytochrome P4501A1 in teleosts: sustained induction of CYP1A1 mRNA, protein, and catalytic activity by $2,3,7,8$-Tetrachlorodibenzofuran in the marine fish (Stenotomus chrysops). Toxicol. Appl. Pharmacol. 127(2):187-98.

Håkansson, H., Johansson, L., Manzoor, E. and Ahlborg, U.G. 1991. Effects of 2,3,7.8-tetrachlorodibenzo-p-dioxin (TCDD) on the vitamin A status of Hartley guinea pigs, C57B1/6 mice. DBA/2 mice and Golden Syrian hamsters. J. Nutr. Sci. Vitaminol. 37:117-38.

Hankinson, O. 1995. The aryl hydrocarbon receptor complex. Ann. Rev. Pharmacol. Toxicol. 35:307-40.

Helle, E., Olsson, M. and Jensen, S. 1976. PCB levels correlated with pathological changes in seal uteri. Ambio 5(5-6):261-3.

Ishida, C., Koga, N., Hanioka, N., Saeki, H.K. and Yoshimura, H. 1991. Metabolism in vitro of 3,4,3',4'- and $2,5,2 ', 5$-tetrachlorobiphenyl by rat liver microsomes and highly purified cytochrome P-450. $J$. Pharmacobio-Dynamics 14:276-84.

Jansen, H.T., Cooke, P.S., Porcelli, J., Liu, T.-C. and Hansen, L.G. 1993. Estrogenic and antiestrogenic actions of $\mathrm{PCBs}$ in the female rat: in vitro and in vivo studies. Reproductive Toxicol. 7:237-48.

Kannan, N., Tanabe, S. and Tatsukawa, R. 1988. Potentially hazardous residues of non-ortho chlorine substituted coplanar PCBs in human adipose tissue. Arch. Environ. Health 43(1):11-4.

Kannan. N.. Tanabe, S., Ono, M. and Tatsukawa, R. 1989a. Critical evaluation of polychlorinated biphenyl toxicity in terrestrial and marine mammals: increasing impact of non-ortho and mono-ortho coplanar polychlorinated biphenyls from land to ocean. Arch. Environ. Contam. Toxicol. 18:850-7.

Kannan, N., Tanabe, S., Tatsukawa, R. and Phillips, D.J.H. 1989b. Persistency of highly toxic coplanar PCBs in aquatic ecosystems: uptake and release kinetics of coplanar PCBs in green-lipped mussels (Perna viridis Linnaeus). Environ. Pollut. 56:65-76.

Kannan, N., Reusch, T.B.H., Schulz-Bull, D.E., Petrick, G. and Duinker, J.C. 1995. Chlorobiphenyls: model compounds for metabolism in food chain organisms and their potential use as ecotoxicological stress indicators, by application of the metabolic slope concept. Environ. Sci. Technol. 29:1851-9.

Kennedy, S. 1999. Contaminants and morbilliviral epizootics in marine mammals. J. Cetacean Res. Manage. (special issue) 1:267-73.

Klasson-Wehler, E. 1989. Synthesis of some radiolabelled organochlorines and metabolism studies in vivo of two PCBs. Thesis, ReproPrint AB, Stockholm.

Klasson-Wehler, E., Brunström, B., Rannug, U. and Bergman, $\AA$. 1990. 3,3',4,4'-tetrachlorobiphenyl: metabolism by the chick embryo in ovo and toxicity of hydroxylated metabolites. Chem.-Biol. Interact 73:121-32.

Klasson-Wehler, E., Kuroki, H., Athanasiadou, M. and Bergman, $\AA$. 1992. Selective retention of hydroxylated PCBs in blood. Organohalogen Compounds 10:121-2.

Koga, N., Beppu, M. and Yoshimura, H. 1990. Metabolism in vivo of 3,4,5,3',4'-pentachlorobiphenyl and toxicological assessment of the metabolites in rats. J. Pharmacobio-Dynamics 13:497-506.

Koopman-Esseboom, C., Huisman, M., Weisglas-Kuperus, N., Van der Paauw, C.G., Tuinstra, L.G.M.T., Boersma, E.R. and Sauer, P.J.J. 1994. PCB and dioxin levels in plasma and human milk of 418 Dutch women and their infants: predictive value of PCB congener levels in maternal plasma for fetal and infant's exposure to PCBs and dioxins. Chemosphere 28(9):1721-32.

Korach, K.S., Sarver, P., Chae, K., McLachlan, J.A. and McKinney, J.D. 1987. Estrogen receptor binding activity of polychlorinated hydroxybiphenyls: conformationally restricted structural probes. Mol. Pharmacol. 33:120-6.

Lans, M.C., Kubiczak, G., Douwes, J. and Brouwer, A. 1990. In vitro effects of 3,4,3',4' tetrachlorobiphenyl and its hydroxy metabolites on mitochondrial function. Organohalogen Compounds 1:103-6.

Lans, M.C., Klasson-Wehler, E., Willemsen, M., Meussen, E., Safe, S.H. and Brouwer, A. 1993. Structuredependent competitive interaction of hydroxy-polychlorobiphenyls, -dibenzo-p-dioxins and -dibenzofurans with human transthyretin. Chem.-Biol. Interact 88:7-21. 
Lu, J.R., Miyata, H., Huang, C.-W., Tsai, H.-T., Sheng, V.-Z., Yoshitake, Y., Nakao, T., Mase, Y., Aozasa, O. and Ohta, S. 1994. Levels of PCDDs, PCDFs and non-ortho chlorine substituted coplanar PCBs in fish and crab from culture ponds and a coastal area near incineration sites from metal reclamation in Wan-Li, Taiwan, Republic of China. Organohalogen Compounds 20:169-74.

McConnell, E.E. 1989. Acute and chronic toxicity and carcinogenesis in animals. pp. 161-93. In: R.D. Kimbrough and A.A. Jensen (eds.) Halogenated Bipheny/s, Terphenyls, Naphthalenes, Dibenzodioxins and Related Products. 2nd. Edn. Elsevier, Amsterdam.

Miyata, H., Aozasa, O., Yamamori, K., Fujiwara, A. and Yasuda, Y. 1994. Survey on pollution of dioxin and related compounds monitored by blue mussel as a biological indicator at 24 coastal areas in Japan. Organohalogen Compounds 20:187-90.

Morse, D.C. 1995. Polychlorinated biphenyl-induced alterations of thyroid hormone homeostasis and brain development in the rat. Doctoral Thesis, Agricultural University Wageningen.

Morse, D.C., Van der Pas, M., Klasson-Wehler, E., De Bie, A.T., Van Bladeren, P.J. and Brouwer, A. 1995. Melabolism and biochemical effects of 3,3',4,4'-tetrachlorobiphenyl in pregnant and fetal rats. Chem.-Biol. Interact 95:41-56.

Murk, A.J., Bosveld, A.T.C., Van der Berg, M. and Brouwer, A. 1994a. Effects of polyhalogenated aromatic hydrocarbons (PHAHs) on biochemical parameters in chicks of the common tern (Sterna hirundo). Aquat. Toxicol. 30:91-115.

Murk, A.J., Morse, D.C., Boon, J.P. and Brouwer, A. 1994b. In vitro metabolism of 3,3',4,4'-tetrachlorobiphenyl in relation to ethoxyresorufin- $O$-deethylase activity in liver microsomes of some wildlife species and rat. Eur. J. Pharmacol. 270:253-61

Murk, A.J., Van den Berg, J.H.J., Fellinger, M., Rozemeijer, M.J.C., Swennen, C., Duiven, P., Boon, J.P., Brouwer, A. and Koeman, J.H. 1994c. Toxic and biochemical effects of 3,3',4,4'-tetrachlorobiphenyl (CB77) and Clophen A50 on eider ducklings (Somateria mollisima) in a semi-field experiment. Environ. Pollut. 86:21-30.

Narasimhan, T.R., Kim, H.L. and Safe, S.H. 1991. Effects of hydroxylated polychlorinated biphenyls on mouse liver mitochondrial oxidative phosphorylation. J. Biochem. Toxicol. 6(3):229-36.

Nebert, D.W., Puga, A. and Vasiliou, V. 1993. Role of the Ah receptor and the dioxin-inducible [Ah] gene battery in toxicity, cancer and signal transduction. Amm. NY Acad. Sci. 685:624-40.

Norstrom, R.J. and Muir, D.C.G. 1994. Chlorinated hydrocarbon contaminants in Arctic marine mammals. Sci. Total Environ. 154(2-3):107-28.

Norstrom, R.J., Simon, M., Muir, D.C.G. and Schweinsburg, R.E. 1988. Organochlorine contaminants in arctic marine food chains: identification, geographical distribution and temporal trends in polar bears. Environ. Sci. Technol. 22:1063-71.

Oehme, M., Haugen, J.-E., Kallenborn, R. and Schlabach, M. 1994a. Polychlorinated compounds in Antarctic air and biota: similarities and differences compared to the Arctic. Organohalogen Compounds 20:523-8.

Oehme, M., Schlabach, M., Hummert, K., Luckas, B. and Norday, E.S. 1994b. Levels of polychlorinated dibenzo-p-dioxins, dibenzofurans, biphenyls and pesticides in harp seals from the Greenland Sea. Organohalogen Compounds 20:517-22.

Ohsaki, Y., Matsueda, T. and Kurokawa, Y. 1994. Levels and features of PCDDs, PCDFs and Co-PCBs in river and coastal sediments. Organohalogen Compounds $20: 111-4$.

Peterson, R.E., Theobald, H.M. and Kimmel, G.L. 1993. Developmental and reproductive toxicity of dioxins and related compounds: cross-species comparisons. Crit. Rev. Tovicol. 23(3):283-335.

Poland, A. and Knutson, J.C. 1982. 2,3,7,8-Tetrachlorodibenzo-p-dioxin and related halogenated aromatic hydrocarbons: examination of the mechanism of toxicity. Ann. Re'v. Phamacol. Toxicot. 22:517-54.

Reijnders, P.J.H. 1986. Reproductive failure in common seals feeding on fish from polluted coastal waters. Nature, Lond. 324:456-7.

Reijnders, P.J.H. 1994. Toxicokinetics of chlorobiphenyls and associated physiological responses in marine mammals, with particular reference to their potential for ecotoxicological risk assessment. Sci. Total Environ. 154(2-3):229-36.

Reijnders, P.J.H. and de Ruiter-Dijkman, E.M. 1995. Toxicological and epidemiological significance of pollutants in marine mammals. pp. 575-87. In: A.S. Blix, L. Walloe and Ø. Ulltang (cds.) Whales, Seals, Fish and Man. Elsevier Science BV, Amsterdam.

Roberts-Thomson, S.J., McManus, M.E., Tukey, R.H., Gonzales, F.J. and Holder, G.M. 1995. Metabolism of polycyclic Aza-Aromatic carcinogens catalysed by four expressed human cytochromes P450. Cancer Rescirch 55(5):1052-9.

Ross, P.S., De Swart, R.L., Reijnders, P.J.H., Loveren, H.V., Vos, J.G. and Osterhaus, A.D.M.E. 1995. Contaminant related suppression of delayed-type hypersensitivity and antibody responses in harbour seals fed herring from the Baltic Sea. Emiron. Health Pe'spect. 103(2):162-7. 
Safe, S. 1989. Polyhalogenated aromatics: uptake, disposition and metabolism. pp. 131-59. In: R.D. Kimbrough and A.A. Jensen (eds.) Halogenated Biphenyls, Terphenyls, Naphthalenes, Dibenzodioxins and Related Products. Elsevier, Amsterdam. 518pp.

Safe, S.H. 1994. Polychlorinated biphenyls (PCBs): environmental impact, biochemical and toxic responses and implications for risk assessment. CRC Critical Rev. Toxicol. 24:87-149.

Tanabe, S., Watanabe, S., Kan, H. and Tatsukawa, R. 1988. Capacity and mode of PCB metabolism in small cetaceans. Mar. Mammal Sci. 4(2):103-24.

Van Birgelen, A.P.J.M., Smit. E.A.. Kampen, I.M., Groeneveld, C.N., Fase, K.M., Van der Kolk, J., Poiger, H., Van den Berg, M., Koeman, J.H. and Brouwer, A. 1995. Subchronic effects of 2,3,7,8-TCDD or PCBs on thyroid hormone metabolism: use in risk assessment. Eur. J. Pharmacol.: Env. Toxicol. Pharmacol. Section 293:77-85.

Van den Berg, M., Craane, B.L.H.J., Sinnige, T., Van Mourik, S., Dirksen, S., Boudewijn, T., Van der Gaag, M.. Lutke-Schipholt, I.J., Spenkelink, B. and Brouwer, A. 1994a. Biochemical and toxic effects of polychlorinated biphenyls (PCBs), dibenzo-p-dioxins (PCDDs), and dibenzofurans (PCDFs) in the cormorant (Phalacrocorax carbo) after in ovo exposure. Environ. Toxicol. Chem. 13(5):803-16.

Van den Berg, M., De Jongh, J., Poiger, H. and Olson, J.R. 1994b. The toxicokinetics and metabolism of polychlorinated dibenzo-p-dioxins (PCDDs) and dibenzofurans (PCDFs) and their relevance for toxicity. Crit. Rev. Toxicol. 24:1-74.

Vethaak, A.D. 1993. Fish disease and marine pollution. Doctoral Thesis, University of Amsterdam.

Visser, T.J., Kaptein, E., Van Toor, H., Van Raay, J.A.G.M., Van den Berg, K.J., Tjong Tjin Joe, C., Van Engelen, J.G.M. and Brouwer, A. 1993. Glucuronidation of thyroid hormone in rat liver: Effects of in vivo treatment with microsomal enzyme inducers and in vitro assay conditions. Endocrinology $133: 2,177-86$

White, R.D., Hahn, M.E., Lockhart, L.L. and Stegeman, J.J. 1994. Catalytic and immunochemical characterisation of hepatic microsomal cytochromes P450 in beluga whale (Delphinapterus leucas). Toxicol. Appl. Pharmacol. 126:45-57.

Whitlock, J.P. 1993. Mechanistic aspects of dioxin action. Chem. Res. Toxicol. 6:745-53.

Yang, S.K., Mushtaq, M. and Chiu, P.L. 1984. Stereoselective metabolism and activation of polycyclic aromatic hydrocarbons. pp. 19-34. In: R.G. Harvey (ed.) Polycyclic Hydrocarbons and Carcinogenesis. American Chemical Society, Washington.

Yoshimura, H., Yonemoto, Y., Yamada, H., Koga, N., Oguri, K. and Saeki, S. 1987. Metabolism in vivo of $3,4,3^{\prime}, 4^{\prime}$-tetrachlorobiphenyl and toxicological assessment of the metabolites in rats. Xenobiotica 17:897-910.

Zile, M.H., Bank, P.A. and Roltsch, I.A. 1989. Alterations in vitamin A metabolism by polyhalogenated aromatic hydrocarbons. Z. Ernahrungswiss. 28:93-102. 